\title{
Burial and exhumation history of the Labrador- Newfoundland margin: first observations
}

\author{
Peter Japsen, Paul F. Green, Johan M. Bonow, Alana M. Hinchey and Derek H.C. Wilton
}

The continental shelf of Labrador and Newfoundland has a long history of hydrocarbon exploration, and the accumulated oil production from the northern Grand Banks exceeds one billion barrels (Fig.1). The Canada-Newfoundland \& Labrador Offshore Petroleum Board (www.cnlopb.ca) awarded several new licenses on the northern Grand Banks in 2015 and announced licensing rounds for the Labrador Sea region in the coming years.

Vertical motion along passive continental margins such as the Atlantic margin of Canada, plays an essential role in shaping these margins and their petroleum systems; in particular by removing sedimentary strata (Japsen et al. 2012; Green et al. 2013). It is thus a fundamental question whether a hiatus in the stratigraphic record represents an episode of stability and non-deposition or an event involving deposition followed by removal of rocks. In this context, a hiatus represents not only a gap in the stratigraphic record, but also a gap in our understanding of the geological history.

In terms of hydrocarbon systems, failure to account for greater depths of burial prior to exhumation can lead to serious underestimation of the maturity of petroleum resources. Similarly, the effects of exhumation on the timing of hydrocarbon generation, on changes in migration routes and on any reservoir hydrocarbons also require assessment (Doré et al. 2002). Insights into the uplift history of a margin are also important for understanding the source-tosink system of sediment input into offshore basins.

In broader terms of geological development, understanding the history of vertical movements along a passive continental margin is important for investigating whether the elevated regions along these margins, such as the Torngat Mountains in northern Labrador (Fig. 1), are either (a) the eroded remnants of ancient orogens (McGregor et al. 2013), (b) rift shoulders related to processes during rifting and break-up (Weissel \& Karner 1989) or (c) the results of postbreakup episodes of burial and exhumation driven by platetectonic forces (Japsen et al. 2006, 2012; Green et al. 2013).

Studies of the burial and exhumation history both onshore and offshore of Labrador and Newfoundland are, however, scarce, but several observations - that we review in the following - indicate that a number of uplift episodes followed by denudation, both pre- and post-breakup, shaped the present-day structure of the margin.

\section{Evidence for episodes of burial and exhumation of the margin}

The Atlantic margin of Canada has many features in common with passive continental margins in other parts of the world (Japsen et al. 2012; Green et al. 2013), such as elevated plateaux (i.e. regional high-level landscapes of low, relative relief) at 1 to $2 \mathrm{~km}$ or more above sea level (a.s.l.) cut by deeply incised valleys and commonly separated from an adjacent coastal plain by one or more escarpments. The Torngat Mountains with peaks reaching $1.7 \mathrm{~km}$ a.s.l. in northern Labrador, slope much more steeply towards the Labrador Sea than they do towards the hinterland farther



Fig. 1. Outline of the study area, c. $1500 \mathrm{~km}$ along the Labrador-Newfoundland margin between 46 and $60.5^{\circ} \mathrm{N}$. Yellow star: Cretaceous outlier at Schefferville (Dorf 1967). AFTA: Apatite fission-track analysis. 

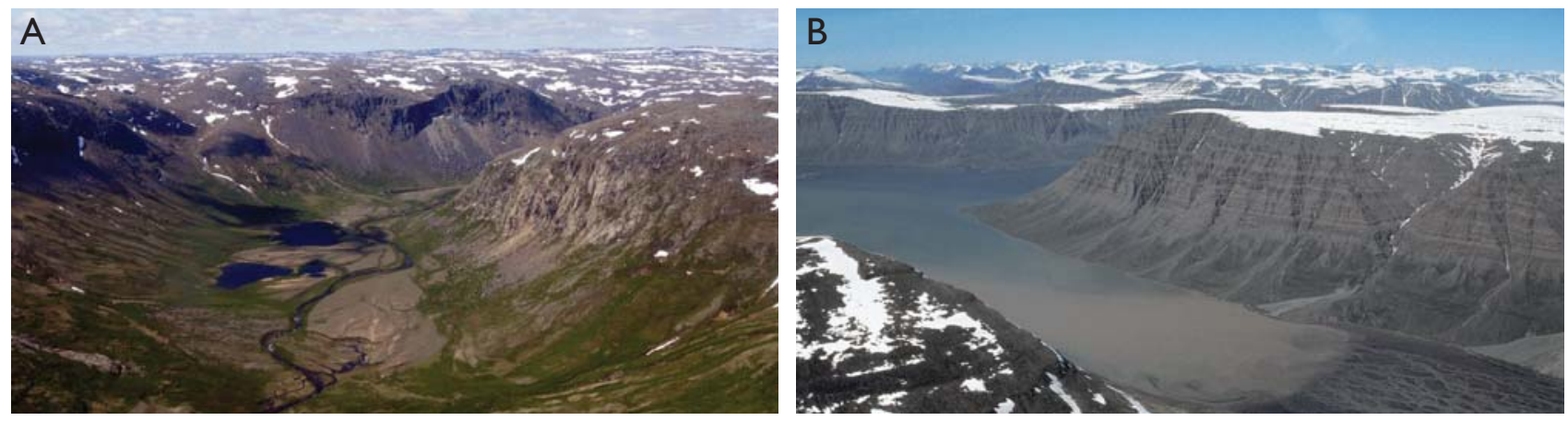

Fig. 2. Similar landscapes on the conjugate margins across the Labrador Sea. A: Elevated plain (c. $800 \mathrm{~m}$ a.s.l.) across Precambrian basement cut by a deep valley, Torngat Mountains, Labrador. B: Elevated plain (c. $900 \mathrm{~m}$ a.s.l.) across Paleocene basalts cut by a deep valley, Disko island, West Greenland. The study will investigate whether the elevated plain is a Cenozoic erosion surface as it is the case for the conjugate margin in West Greenland (Bonow et al. 2006; Japsen et al. 2006). Photo locations in Fig. 1.

west in interior Labrador, and their overall shape is thus similar to that of the coastal mountains in Greenland (Fig. 2). However, farther south (e.g. on Newfoundland) elevations do not reach $1 \mathrm{~km}$ a.s.l. As along other passive margins, Mesozoic-Cenozoic rift systems parallel the Labrador-Newfoundland margin with a transition from continental to oceanic crust farther offshore. Here breakup occurred in the Early Cretaceous east of Newfoundland and in the Paleocene east of Labrador. The syn- and post-rift sediments at the landward margin of these rifts dip towards the rifts and are truncated by one or more shallow unconformities or by the seabed (Fig. 3). In particular, the margin of Labrador shares the characteristics listed above with the conjugate margin of West Greenland where the geological record documents that the present-day high mountains are not remnants of the rifting process but the result of much later uplift which partially removed thick, post-rift deposits (Japsen et al. 2006).

\section{Evidence from the offshore domain}

Dickie et al. (2011) noted that the Tertiary sediments along Labrador are tilted seaward and truncated (Fig. 3), and that late Oligocene as well as younger (possibly Miocene) unconformities might correspond to phases of uplift of the Labrador margin as proposed by McMillan (1973). According to Dickie et al. (2011), the sedimentary record along the Labrador margin is difficult to interpret because of the limited dating of the younger, post-Oligocene section, and the many phases of channelling and erosion that are exhibited. Subsequently, Ainsworth et al. (2014) studied the Cretaceous-Tertiary stratigraphy of the Labrador Shelf and provided improved constraints on several unconformities; in particular they documented the presence of a regional Miocene hiatus. Figure 4 shows evidence that the pre-Pliocene sequences along Labrador have been more deeply buried in the past, most likely prior to the removal of Miocene strata. Also on the Grand Banks, uplift and exhumation were important processes for the shaping of petroleum systems (Sinclair et al. 1994; Avery 2001).

\section{Evidence from the onshore domain}

Precambrian rocks dominate Labrador and Newfoundland, but Phanerozoic cover rocks are present across the region, for example in the Palaeozoic basins of western Newfoundland (Cooper et al. 2001). Hendriks et al. (1993) interpreted apatite fission-track data from western Newfoundland to indicate major episodes of late Carboniferous and Jurassic exhumation, which agree with evidence from thermal maturity of Palaeozoic rocks that they had been more deeply buried below a cover up to $3 \mathrm{~km}$ thick (Wil-

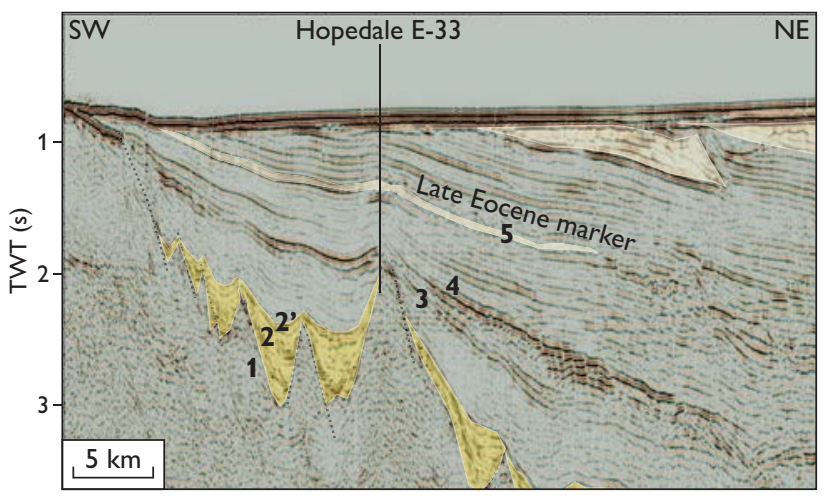

Fig. 3. Seismic profile off Labrador illustrating post-Eocene tilting and truncation of the sedimentary sequences (after Dickie et al. 2011). Unconformities: 5: late Eocene. 4: base Eocene. 3: mid-Paleocene. 2': Late Cretaceous. 2: mid-Cretaceous. 1: top basement. Sand-prone units: Gold and yellow colours. Location on Fig. 1. TWT: two-way travel time. 


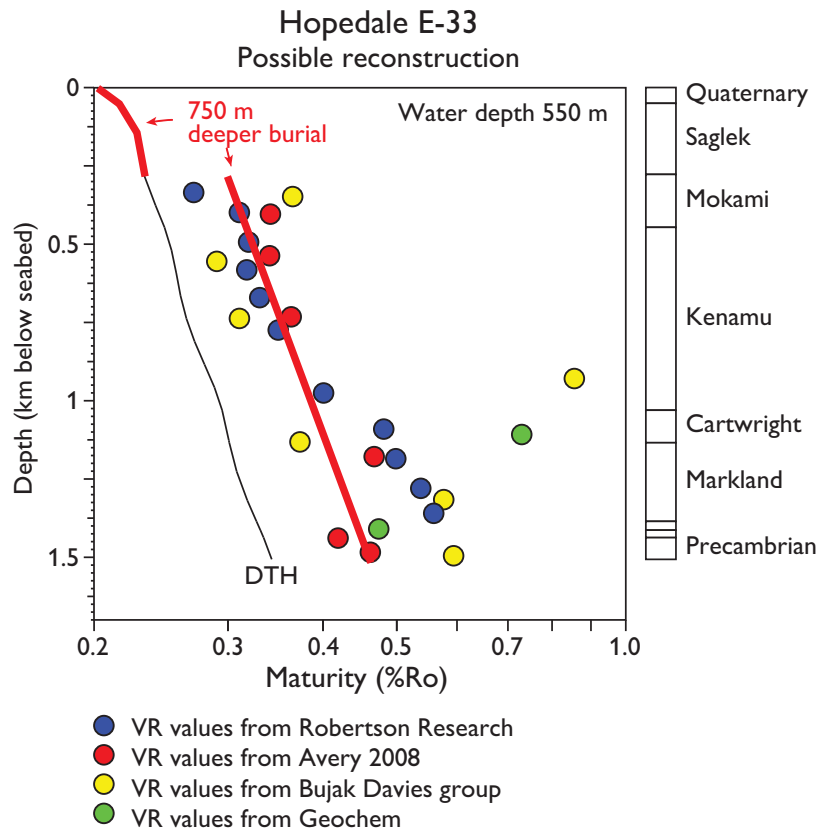

Fig. 4. Scattered vitrinite reflectance (VR) data from various labs for the Hopedale E-33 well (source: Canada Basin Database; http://basin. gdr.nrcan.gc.calindex_e.php; location in Figs 1,3). The solid black line shows the profile predicted if all units in the well are currently at their maximum post-depositional temperatures (default thermal history, DTH). All values plot consistently above the black line, suggesting that units below the Plio-Pleistocene Saglek Formation have been hotter in the past, although a detailed interpretation of these data is not possible because of the scatter in the data and differences between datasets. The red profile shows the prediction from a history in which the pre-Saglek section has been buried more deeply by $750 \mathrm{~m}$ prior to exhumation.

liams et al. 1998). Pe-Piper \& MacKay (2006) presented evidence for Early Cretaceous drainage from western Newfoundland to areas onshore and offshore Nova Scotia.

An outlier of Cretaceous sediments on central Labrador around Schefferville (Dorf 1967) constrains the construction of a relative denudation chronology based on stratigraphic landscape analysis and for thermochronological modelling by documenting when basement rocks were exhumed to the surface. White et al. (2000) included the Schefferville outlier in their evidence for an Albian connection between the Labrador Sea and the Cretaceous Western Interior Seaway of North America.

Grist \& Zentilli (2003) reported evidence for post-Jurassic exhumation with as much as $30^{\circ} \mathrm{C}$ of post-Paleocene cooling of the southern portion of the Canadian Atlantic margin, based on fission-track data from e.g. Nova Scotia. They also reported high vitrinite reflectance values for Jurassic strata in the Fundy Basin, offshore Nova Scotia, in agreement with $2 \mathrm{~km}$ of post-Jurassic erosion inferred from seismic data.

\section{Integrated investigation of the vertical movements along the margin}

The observations reviewed above demonstrate that episodes of burial and exhumation have affected the Atlantic margin of Canada both prior to and after break-up. The available evidence does not, however, allow further definition of the timing and magnitude of the vertical movements that shaped the present-day margin. In particular, it is not possible to define when the mountains along the margin reached their present elevation. We have therefore initiated a research project aimed at defining the main events of burial and exhumation along the margin onshore and offshore Labrador and Newfoundland (Fig. 1). The study has three components:

(1) A thermochronological study based on samples from outcrops and from onshore and offshore boreholes with associated thermal history interpretations (Green et al. 2013). A pilot study comprising apatite fission-track analysis (AFTA) data in 12 samples (Fig. 1) revealed a long history of Phanerozoic cooling and exhumation episodes, notably a regional Triassic event during which a sample of latest Neoproterozoic sandstone collected in St. John's cooled below $110^{\circ} \mathrm{C}$, corresponding to the onset of removal of a kilometre-thick cover of Palaeozoic-Triassic rocks.

(2) A stratigraphic landform analysis of the study area based on digital elevation data and stratigraphic information to map exposed denudation surfaces. This analysis provides evidence of both uplift and subsidence using cross-cutting relationships between palaeosurfaces (onshore unconformities expressed as large-scale, low-relief surfaces produced by erosion to base level) and stratigraphic constraints. We intend to use this analysis to construct a relative chronology for surface formation and tectonic events (Green et al. 2013).

(3) An integrated interpretation of the geological, geomorphological and thermochronological data. We will combine the relative denudation chronology from the stratigraphic landscape analysis with the absolute timing of cooling events determined from the AFTA data in order to estimate the timing and magnitude of uplift and exhumation along the margins of Labrador and Newfoundland.

Studying uplift/exhumation with just one technique in isolation provides only part of the story. Without the AFTA data, the landform analysis will only yield a relative event chronology. Without the landform analysis, it will not be possible to conclude whether surface uplift accompanied exhumation as recorded by the AFTA data.

\section{Summary}

The stratigraphic record along the continental margin of Labrador and Newfoundland provides ample evidence for 
vertical movements both prior to and after break-up; on the island of Newfoundland, late Carboniferous and Jurassic phases of exhumation removed kilometre-thick covers over Palaeozoic basins (Hendriks et al. 1993; Williams et al. 1998), and in Labrador, Cretaceous sediments rest on Precambrian basement (Dorf 1967). In the offshore domain, several major hiatuses punctuate the stratigraphic record; e.g. along Labrador between the Palaeozoic sediments and Precambrian basement and between Lower Cretaceous volcanics and underlying Palaeozoic sediments, intra-Cretaceous and base-Tertiary unconformities and several intraTertiary unconformities (mid-Paleocene, late Eocene, midOligocene and Miocene; Ainsworth et al. 2014). It is our ambition to combine the evidence from the stratigraphic record with results from stratigraphic landscape analysis and thermochronology to provide a coherent model of the timing and magnitude of the vertical movements along the margin both prior to and after break-up.

\section{Acknowledgements}

We thank sponsoring oil companies for financial support and the Geological Survey of Newfoundland and Labrador for funding the AFTA pilot study.

\section{References}

Ainsworth, N.R., Riley, L., Bailey, H.W. \& Gueinn, K.J. 2014: Cretaceous-Tertiary stratigraphy of the Labrador Shelf, Riley Geoscience Ltd., commissioned by Nalcor Energy, http://www.nalcorenergy.com/ OILGAS/labrador-biostratigraphy.asp

Avery, M.P. 2001: Vitrinite reflectance (Ro) of dispersed organic matter from Husky/Bow Valley et al. Golconda C-64. GSC Open File Report 4013, 14 pp., http://basin.gdr.nrcan.gc.ca/wells/single_maturation_e. php?well=D302

Bonow, J.M., Japsen, P., Lidmar-Bergström, K., Chalmers, J.A. \& Pedersen, A.K. 2006: Cenozoic uplift of Nuussuaq and Disko, West Greenland - elevated erosion surfaces as uplift markers of a passive margin. Geomorphology 80, 325-337.

Cooper, M., Weissenberger, J., Knight, I., Hostad, D., Gillespie, D., Williams, H., Burden, E., Porter-Chaudhry, J., Rae, D. \& Clark, E. 2001: Basin evolution in western Newfoundland: New insights from hydrocarbon exploration. AAPG Bulletin 85, 393-418.

Dickie, K., Keen, C.E., Williams, G.L. \& Dehler, S.A. 2011: Tectonostratigraphic evolution of the Labrador margin, Atlantic Canada. Marine and Petroleum Geology 28, 1663-1675.
Doré, A.G., Cartwright, J.A., Stoker, M.S., Turner, J.P. \& White, N. (eds) 2002: Exhumation of the North Atlantic margin: timing, mechanisms and implications for petroleum exploration. Geological Society, London, Special Publications 196, 494 pp.

Dorf, E. 1967: Cretaceous insects from Labrador I. Geologic Occurrence. Psyche 74, 267-269.

Green, P.F., Lidmar-Bergström, K., Japsen, P., Bonow, J.M. \& Chalmers, J.A. 2013: Stratigraphic landscape analysis, thermochronology and the episodic development of elevated passive continental margins. Geological Survey of Denmark and Greenland Bulletin 30, 150 pp.

Grist, A. \& Zentilli, M. 2003: Post-Paleocene cooling in the southern Canadian Atlantic region: evidence from apatite fission track models. Canadian Journal of Earth Sciences 40, 1279-1297.

Hendriks, M., Jamieson, R.A., Willett, S.D. \& Zentilli, M. 1993: Burial and exhumation of the Long Range inlier and its surroundings, western Newfoundland: results of an apatite fission-track study. Canadian Journal of Earth Sciences 30, 1594-1606.

Japsen, P., Bonow, J.M., Green, P.F., Chalmers, J.A. \& Lidmar-Bergström, K. 2006: Elevated, passive continental margins: Long-term highs or Neogene uplifts? New evidence from West Greenland. Earth and Planetary Science Letters 248, 315-324.

Japsen, P., Chalmers, J.A., Green, P.F. \& Bonow, J.M. 2012: Elevated, passive continental margins: Not rift shoulders, but expressions of episodic, post-rift burial and exhumation. Global and Planetary Change 90-91, 73-86.

McGregor, E.D., Nielsen, S.B., Stephenson, R., Petersen, K.D. \& Macdonald, D.I.M. 2013: Long-term exhumation of a Palaeoproterozoic orogen and the role of pre-existing heterogeneous thermal crustal properties: a fission-track study of SE Baffin Island. Journal of the Geological Society, London 170, 877-891.

McMillan, N.J. 1973: Shelves of Labrador Sea and Baffin Bay, Canada. In: McCrossan, R.G. (ed.): Future petroleum provinces of Canada, their geology and potential. Canadian Society of Petroleum Geology, Memoir 1, 473-517.

Pe-Piper, G. \& Mackay, R.M. 2006: Provenance of Lower Cretaceous sandstones onshore and offshore Nova Scotia from electron microprobe geochronology and chemical variation of detrital monazite. Bulletin of Canadian Petroleum Geology 54, 366-379.

Sinclair, I.K., Shannon, P.M., Williams, B.P.J., Harker, S.D. \& Moore, J.G. 1994: Tectonic control on sedimentary evolution of three North Atlantic borderland Mesozoic basins. Basin Research 6, 193-217.

Weissel, J.K. \& Karner, G.D. 1989: Flexural uplift of rift flanks due to mechanical unloading of the lithosphere during extension. Journal of Geophysical Research - Solid Earth 94, 13919-13950.

White, T.S., Witzke, B.J. \& Ludvigson, G.A. 2000: Evidence for an Albian Hudson arm connection between the Cretaceous Western Interior Seaway of North America and the Labrador Sea. Geological Society of America Bulletin 112, 1342-1355.

Williams, S.H., Burden, E.T. \& Mukhopadhyay, P.K. 1998: Thermal maturity and burial history of Paleozoic rocks in western Newfoundland. Canadian Journal of Earth Sciences 35, 1307-1322.

\footnotetext{
Authors' addresses

P.J., Geological Survey of Denmark and Greenland (GEUS), Øster Voldgade 10, DK-1350 Copenhagen K, Denmark. E-mail: pj@geus.dk

P.F.G., Geotrack International, 37 Melville Road, Brunswick West, Victoria 3055, Australia.

J.M.B., Geovisiona AB, Högbyvägen 168, SE-17554 Järfälla, Sweden and Mid Sweden University, Kunskapens väg 1, SE-831 25 Östersund, Sweden.

A.M.H., Geological Survey, Department of Natural Resources, Government of Newfoundland and Labrador, P.O. Box 8700, St. John's, Canada NL A1B $4 J 6$.

D.H.C.W., Memorial University of Newfoundland, P.O. Box 4200, St. John's, Canada NL A1C 5 S7.
} 